\title{
Insect Fat, a Promising Resource for Biodiesel
}

Qing $\mathrm{Li}^{1,2}$, Longyu Zheng ${ }^{1}$, Yanfei Hou ${ }^{1}$, Sheng Yang ${ }^{1}$ and Ziniu $\mathrm{Yu}^{1 *}$

${ }^{1}$ State Key Laboratory of Agricultural Microbiology, National Engineering Research Centre of Microbial Pesticides, Huazhong Agricultural University, Wuhan, P. R. China ${ }^{2}$ College of Science, Huazhong Agricultural University, Wuhan, P. R. China

\begin{abstract}
Biodiesel is one promising approach to reduce the consumption of petroleum. However, biodiesel economy has been hampered by the production of oilseed plants. Therefore, alternative feedstocks are urgently needed to enable biodiesel production from cheaper materials. Insect recourse which is rated as the most diverse animal group is rich and ubiquitous in the world. Insect could convert organic waste into insect fat which was further extracted as a novel feedstock for biodiesel production, and then the residual after extraction can be used as protein feedstuff. This paper reviewed the research and developmental progress on insect fat, especially the possibility of insect fat as potential feedstock of biodiesel.
\end{abstract}

Keywords: Biodiesel; Biomass; Organic wastes; Insect fat; Fatty acids Introduction

Biodiesel is a form of diesel made from vegetable oils, animal fats, or recycled restaurant greases. As a renewable fuel, biodiesel is an important resource to provide energy for the world's transportation needs $[1,2]$. Promotion of biodiesel, technology is not a limited factor, but the raw material of biodiesel [3]. The raw materials being exploited commercially are the edible oils such as rapeseed, soybean, palm, sunflower, etc, and which also are basic requirement as food [4]. Moreover, the cost of feedstock is a major economic factor in the development of biodiesel [5]. One of the ways is to reduce the costs of biodiesel by using the cheaper feedstock. In this context, some had searched for new renewable feedstock for biodiesel, such as microalgae [6], and Jatropha curcas [7]. Whereas this feedstock is very challenging to be conquered; most are at the laboratory scale.

Therefore, seeking solutions to energy and society cannot affect the local environmental and societal benefits, the alternative feedstock should be technically feasible, economically competitive, environmentally acceptable, and easily available [8]. For example, Hermetia illucens $L$., which is usually known as black soldier fly (BSF), can convert organic wastes into useful products with no competing with food [9].

\section{Development of fat-rich insect resources}

Insect had long natural evolutionary history; the history of winged insect was at least 3.5 million years. As one of the largest biomass in the world, insect could be found everywhere from the equator to the poles, mountains to the sea, generally could possibly found in every corner of the earth $[10,11]$. The life cycles of insect began from the eggs, and constrained by the inelastic exoskeleton. The immature stages are different from the adults in structure, and habitat can include a passive pupal stage in those groups that complete metamorphosis. Insect those undergo incomplete metamorphosis lack a pupal stage and adults develop through a series of larval stages and some insect move about by walking or flying [12]. Insect is now recognized as an important resource. With the development of life and environmental science, insect fat is also igniting particular interest [13].

As scavenger, many insect feed on and break down dead plant or animal matter, thus making organic nutrients available to the ecosystem. Organic wastes are important foundation for ecosystem. For example, BSF is often associated with the outdoors and livestock, usually around decaying organic wastes such as animal manure or plant material [14]. Adults live and mate and lay their eggs in cracks and crevices near larval habitat. The larva of BSF is a voracious consumer of decaying organic matter including kitchen wastes, spoiled feed, and manure [15].

\section{Function and content of insect fat}

Insect fat play an important role in the course of evolution, it can serve as a support, reproduction, metamorphosis and other energy sources [16]. Fat is the central storage depot for excess nutrients $[17,18]$. In addition, it is a matrix of great biosynthetic and metabolic activity as supporting and protecting different organs. Insect have to expend energy constantly and if they are not feeding, they must live on reserves accumulated in periods of food abundance. Fatty acids are the energy reserves in insect cells and also aid the absorption of vitamins [19].

Fat content of dried insect is showed in Table 1, one can see that fat is very rich in insect biomass which is accounted for about $26.77 \%$ on average (dried insect). Fat content of I. belina reaches $23 \%$; some larvae have higher fat content, such as $R$. phoenicis (66\%). At different growth stages, fat content is subject to change. In general, larval and pupal period are rich in fat. The fat content of pupal stage is usually higher than that of adult stage [21].

\section{Fatty acid composition of insect fat}

The fatty acids can be separated into saturated fatty acid and unsaturated fatty acid. Unsaturated fatty acid can help human growth, protect the skin and reduce the formation of thrombosis. The unsaturated fatty acids are abundant in insect fat; and the ratio of monounsaturated and polyunsaturated fatty acids are close to the fatty acids ratio of human standards [22].

*Corresponding author: Ziniu Yu, State Key Laboratory of Agricultural Microbiology, National Engineering Research Centre of Microbial Pesticides, Huazhong Agricultural University, Wuhan, P. R. China, Tel: +86 27 87280802; Fax: +86 27 87393882; E-mail: yz41@mail.hzau.edu.cn

Received October 24, 2011; Accepted November 17, 2011; Published November 19,2011

Citation: Li Q, Zheng L, Hou Y, Yang S, Yu Z (2011) Insect Fat, a Promising Resource for Biodiesel. J Pet Environ Biotechnol S2:001. doi:10.4172/2157-7463. S2-001

Copyright: $\odot 2011 \mathrm{Li} \mathrm{Q}$, et al. This is an open-access article distributed under the terms of the Creative Commons Attribution License, which permits unrestricted use, distribution, and reproduction in any medium, provided the original author and source are credited. 


\begin{tabular}{|c|c|c|c|c|}
\hline Item & I. belina & R. phoenicis & O. rhinocero, & R. belicosus \\
\hline Content \% & $23.38 \pm 0.24$ & $66.61 \pm 0.35$ & $38.12 \pm 1.06$ & $36.12 \pm 0.28)$ \\
\hline
\end{tabular}

Table 1: Fat content (\% wet weight) of some insect [20].

\begin{tabular}{|c|c|c|c|c|c|c|}
\hline Fatty acids & IBL & $\mathrm{RP}$ & OR & MB & $\mathrm{RD}$ & HI [14] \\
\hline C12: 0 & $0.12 \pm 0.03$ & $0.20 \pm 0.03$ & $0.09 \pm 0.03$ & $1.50 \pm 0.28$ & nd & $35.6 \pm 0.1$ \\
\hline C14: 0 & $1.15 \pm 0.45$ & $3.20 \pm 0.12$ & $3.50 \pm 0.10$ & $2.17 \pm 0.06$ & $0.9 \pm 0.6$ & nd \\
\hline C16: 0 & $31.90 \pm 0.28$ & $32.40 \pm 0.58$ & $28.70 \pm 0.32$ & $42.45 \pm 0.20$ & $31.5 \pm 0.7$ & $14.8 \pm 0.4$ \\
\hline C16: 1 & $1.80 \pm 0.17$ & $3.30 \pm 0.20$ & $4.41 \pm 0.18$ & $2.10 \pm 0.02$ & $1.9 \pm 1.1$ & $3.8 \pm 0.2$ \\
\hline C18: 0 & $4.71 \pm 0.21$ & $3.10 \pm 0.13$ & $2.10 \pm 0.03$ & $2.86 \pm 0.10$ & $5.5 \pm 0.2$ & $3.6 \pm 0.1$ \\
\hline C18: 1 & $34.20 \pm 0.11$ & $40.10 \pm 0.72$ & $41.50 \pm 2.91$ & $15.84 \pm 0.40$ & $24.6 \pm 1.5$ & $23.6 \pm 0.3$ \\
\hline C18: 2 & $6.02 \pm 0.73$ & $13.00 \pm 0.20$ & $14.10 \pm 0.31$ & $24.24 \pm 1.08$ & $31.2 \pm 0.3$ & $2.1 \pm 0.3$ \\
\hline C18: 3 & $19.60 \pm 0.06$ & $3.50 \pm 0.10$ & $1.50 \pm 0.05$ & $3.90 \pm 0.60$ & $3.2 \pm 0.2$ & nd \\
\hline
\end{tabular}

$\mathrm{IBL}=I$. belina; $\mathrm{MB}=\mathrm{M}$. belicosus, $\mathrm{RP}=\mathrm{R}$. Phoenicis, $\mathrm{OR}=0$. rhinoceros, $\mathrm{RD}=$ Ruspolia differens, $\mathrm{HI}=H$. illucens.

Table 2: Fatty acid composition of some insect fat [23].

In addition, there are fat-soluble vitamins and other natural active products in the fat of insect. More magically, these are some odd carbon fatty acids which are rarely in plant oil. For example, heptadecanoic acid (17:0) in house fly larvae have reached more than $2 \%$. Studies have discovered that the odd carbon fatty acids have unique function of physiological activity, in particular strong anti-cancer activity [24].

\section{Process to turn organic wastes into biodiesel by insect}

Over the last ten years, biodiesel was produced from edible oil. It was soon found that this way had many problems because it required oil seeds plants which occupy limited arable lands. A biochemical process to turn organic wastes into biodiesel by BSF had been developed. The research showed that BSF were potentially capable of converting most of the nutrients and energy within organic wastes into BSF biomass [25]. Firstly, BSF would secrete powerful digestive enzymes into the organic waste, the complex organic materials were changed into soluble organic molecules (sugar, amino acids, and fatty acids), and secondly soluble organic molecules were changed into the grease of BSF, and then the grease was extracted for biodiesel production. The bioconversion process was shown in the Figure 1.

The research showed that there was no creature on the earth capable of disposing of putrescent waste more quickly and efficiently than BSF. On the surface of the disposal unit, there was a 2- to 4-inch layer of actively feeding larvae in several stages of growth. Over 100,000 active larvae can be found in a typical waste disposal unit. In an experiment conducted in Texas over a period of one year, the results showed that BSF larvae could digest $15 \mathrm{~kg} / \mathrm{m}^{2}$ restaurant food waste every day at least $[26,27]$. BSF had the ability to eat and digest all kinds of biowaste, including meat and dairy products. Enviro-Group had developed and patented a unique BSF bioconversion process without energy, electricity, chemicals, even water. The bioconversion was ideal and easily constructed in the same simple manner. Current business investments are marketing efforts on the promises of producing biodiesel from organic wastes $[28,29]$. Furthermore, the research of Newton indicated that the fat from BSF raised on pig manure were converted into biodiesel, it would yield as much energy as methane production from the same amount of manure [29].

The origin of the feedstock will always affect the final quality of the biodiesel. The properties of biodiesel are determined by compositions of the various fatty esters, such as cold flow, and viscosity. The viscosity of biodiesel derived from insect fat is high, which is due to saturated fatty acid of insect fat. With the increase of saturated fatty acid, the viscosity of biodiesel would be increasing, such as animal fat, and palm oils. Compared to petro-diesel, biodiesel have a much narrower range of temperatures between the cloud point and the pour point. The cold flow properties of biodiesel are dependent on the feedstock from which they are made. The cold filter plug point can be accomplished by blending biodiesels from several origins with a variety of cold flow properties, or by adding cold filter plug point improvers. Biodiesel help to enhance the ignition quality of the diesel with no negative effect on its cold flow properties when it mixes with diesel $[30,31]$.

\section{Other products}

The fat accumulated in the bioconversion of organic wastes by insect was extracted as feedstock for biodiesel production. Moreover, the residue could be further utilized as a refined protein feedstuff. Insect also provide bioconversion on the treatment processes and the environmental conditions. For instance, BSF can digest organic compounds which contain $\mathrm{N}$ and $\mathrm{P}$ [32]. BSF can digest manure of pigs, chickens and other livestock within a week. Due to economic development, we confronted with new challenges in organic wastes

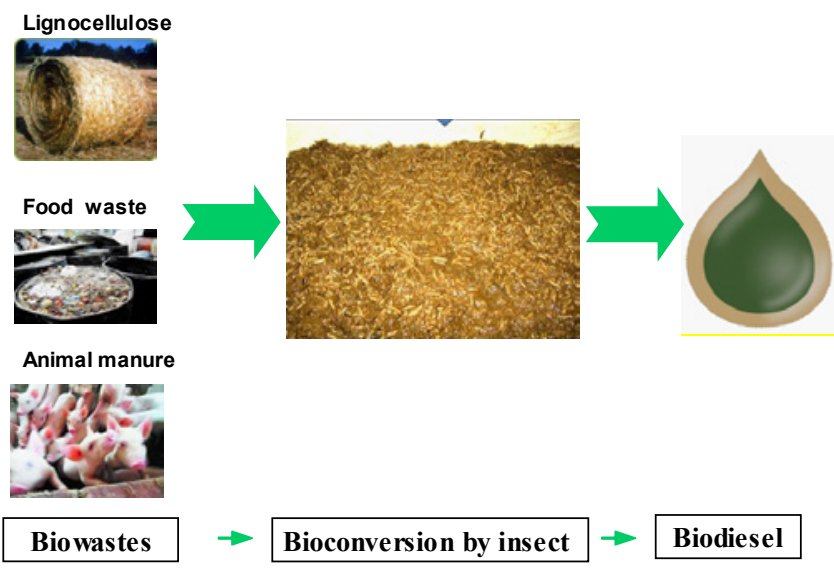

Figure 1: Technical process of bioconversion of organic wastes by insect 
management. Additionally, insect can mitigate the effects of animal manure and industrial sources of organic wastes, the application potential of insect in organic wastes management [33]. Besides the yield of insect fat, BSF, which is high in protein, is good feed for fish and chicken in both backyard and commercial purpose. The lack of global supplies of wild forage fish have make the animal feed industry to look for alternative protein sources in recent years [34].

\section{Closing Remarks}

The cost is the great obstruction of biodiesel, therefore it is important to develop cheap potential resources. Development of biodiesel from insect fat is a new technique. Biodiesel and other products were produced from insect biomass which was converted from organic wastes. Insect biodiesel does not compete with land and food whether small-scale or modern large-scale production. This paper demonstrates that insect holds a high promise for converting organic wastes into valuable products in short lifecycle.

\section{Acknowledgements}

This research was supported by the Fundamental Research Funds for the Central Universities (No2011JC016) and the financial support from Hubei Tianji Bioengineer Corporation (No. 720107-077069).

\section{References}

1. Hill J, Nelson E, Tilman D, Polasky S, Tiffany D ( 2006) Environmental, economic, and energetic costs and benefits of biodiesel and ethanol biofuels. Proc Natl Acad Sci 103: 1206-1210.

2. Ragauskas AJ, Williams CK, Davison BH, Britovsek G, Cairney J et al. (2006) The path forward for biofuels and biomaterials. Science 311: 484-489.

3. Koonin SE ( 2006) Getting serious about biofuels. Science 311: 435

4. David T, Robert S, Jonathan AF, Jason H, Eric L et al. (2009) Beneficial Biofuels-The Food, Energy, and Environment Trilemma. Science 17: 270-271.

5. Fatih MD, Mustafa B, Havva B (2011) Biowastes-to-biofuels. Energ Convers Manage 52: 1815-1828.

6. Huang G, Chen F, Wei D, Zhang X, Chen G (2010) Biodiesel production by microalgal biotechnology. Appl Energ 87: 38-46.

7. Lu H, Liu Y, Zhou H, Yang Y, Chen M et al. (2009) Production of biodiesel from Jatropha curcas L oil. Comput Chem Eng 33: 1091-1096.

8. Lang X, Dalai AK, Bakhshi NN (2001) Preparation and characterization of biodiesels from various bio-oils. Bioresoure Technol 80: 53-62.

9. Sheppard DC, Newton GL, Thompson SA, Savage S (1994) A value added manure management system using the black soldier fly. Bioresoure Technol 50: $275-279$.

10. Angela ED (2007) Symbiotic microorganisms: untapped resources for insect pest control. Trends in Biotechnol 25: 338-342.

11. Liu WC, Bonsall MB, Godfray HCJ (2007) The form of host density-dependence and the likelihood of host-pathogen cycles in forest-insect systems. Theor Popul Biol 72: 86-95.

12. Ola A, Kjell S (1996) Effects of clear-cutting and single-tree selection harvests on herbivorous insect larvae feeding on bilberry (Vaccinium myrtillus) in uneven-aged boreal Picea abies forests. Forest Ecol Manag 87: 139-148.

13. John EB, Riccardo B, Barbara E. (2008) Population response to resource separation in conservation biological control. Biological Control 47: 141-146.

14. Li Q, Zheng L, Qiu N, Cai H, Jeffery K et al. (2011) Bioconversion of dairy manure by black soldier fly (Diptera: Stratiomyidae) for biodiesel and sugar production. Waste Manage 31: 1316-20.

15. Sheppard DC, Newton GL, Thompson SA, Savage S (1994) A value added manure management system using the black soldier fly. Bioresoure Techno 50: $275-279$

16. Estela LA, Jose LS (2010) Insect fat body: Energy, Metabolism, and Regulation. Annu Rev Entomol 55: 207-225.

17. Ellers J (1995) Fat and eggs: an alternative method to measure the tradeoff between survival and reproduction in insect Parasitoids. Neth J Zool 46 : 227-235.

18. Kozhantshikov IW (1938) Carbohydrate and fat metabolism in adult Lepidoptera. B Entomol Res 29: 103-114.

19. Price GM (1973) Protein and nucleic acid metabolism in insect fat body. Biol Rev 48: 333-372.

20. JN Kinyuru, GM Kenji, SN Muhoho, M Ayieko (2010) Nutritioanal potential of longhorn grasshopper (Ruspolia Differns) consumed in siaya distict, KENYA J Agr Sci Tech 12: 33-46.

21. Levinson ZH, Silverman PH (1954) Studies on the Lipids of Musca vicina (Macq.) during Growth and Metamorphosis. Lipids of the housefly 58 : 295-297.

22. De Foliart GR (1991) Insect fatty acids: similar to those or poultry and fish in their degree of unsaturation but higher in the polyunsaturates. Food Insect Newsletter 4: 1-4

23. Ekpo KE, Onigbinde AO, Asia IO (2009) Pharmaceutical potentials of the oils of some popular insect consumed in southern Nigeria. Afr J Pharm Pharmaco 3: 51-57.

24. Vlaeminck B, Lourenc M, Bruinenberg MH, Demeyer D, Fievez V (2004) Odd and branched chain fatty acids in rumen contents and milk of dairy cows fed forages from semi-natural grasslands. Comm Appl Biol Sci 69: 337-340.

25. Li Q, Zheng L, Cai H, Garza E, Yu Z et al. (2011) From organic waste to biodiesel: Black soldier fly, Hermetia illucens, makes it feasible. Fuel 90: 1545-1548.

26. Diener S, Zurbrügg C, Tockner K (2009) Conversion of organic material by black soldier fly larvae: establishing optimal feeding rates. Waste Manag Res 27: 603-610.

27. http://www.esrint.com/pages/bioconversion.html

28. http://www.patentstorm.us/patents/6391620.html

29. Stefan D, Christian Z, Floria RG, Dang HN, Antoine Ml et al. (2011) Black Soldier Fly Larvae for Organic Waste Treatment prospects and constraints. 52 $1-8$

30. Mathew AR, Andreas S (2009) New microbial fuels: a biotech perspective Curr Opin Microbiol 12: 274-281.

31. Ayhan D (2011) Waste management, waste resource facilities and waste conversion processes. Energ Convers Manag 52: 1280-1287.

32. NC State University (2006) Technology Report: Black Soldier Fly (SF) 22

33. Myers HM, Tomberlin JK, Lambert BD, Kattes D (2008) Development of black soldier fly (Diptera: Stratiomyidae) larvae fed dairy manure. Environ Entomol 37: 11-15.

34. Sheppard DC (1983) House fly and lesser house fly control utilizing the black soldier fly in manure management systems for caged laying hens. Environ Entomol 12: 1439-1442. 